\title{
THE CONCEPTS OF ISOLATION, LONELINESS, AND OTHERNESS IN SELECTED ADAPTATIONS OF FRANKENSTEIN
}

\author{
Lida Vakili \\ PHD candidate of Performance Studies at Cultural Centre of University Malaya, Kuala Lumpur, Malaysia \\ Vakili_lida@yahoo.com \\ Ghulam Sarwar Yousof \\ Supervisor and Researcher at Cultural Centre of University Malaya, Kuala Lumpur, Malaysia
}

\begin{abstract}
One of the most recurring characteristics found in monster literature is that of loneliness, and specifically the feelings of isolation which characters are portrayed as suffering. Monsters are often written as fear-inspiring and grotesque, setting them apart from normal society and casting them in the role of 'other'. This, in turn, leads to them being isolated, which can cause them to act in antisocial and sometimes violent ways. This article explores the sense of loneliness portrayed in selected adaptations of Frankenstein, namely Kenneth Branagh's 1994 film version, Mary Shelley's Frankenstein, the X-Files episode "The Post-Modern Prometheus", and Tim Burton's Frankenweenie. Taking into consideration the effect of loneliness on creators and creations within these stories, the article looks at how isolation affects the characters, and how it determines the treatment they receive from other sections of society.
\end{abstract}

Keywords: Frankenstein, loneliness, isolation, otherness

\subsection{INTRODUCTION}

One of the most reputable genres of literature is monster literature, which is a combination of both the decent and the wicked, mostly expecting to provoke a sense of fear and horror in its readers by showing malevolent aspects in the shape of a monster (Sanders 150). The notions and subject of monster literature originated from 18th century Gothic literature, though the monster genre originally appeared in the 19th century with the publication of Mary Shelley's novel, Frankenstein (151). Gothic literature contains the basics of panic and horror, with a victim who is abandoned and pitted against his or her enemy. The enemy most often has paranormal control over the victim, and uses this power to influence them. In monster literature, the enemy is usually shown as a monster that troubles the central character (Jackson 62). Additionally, Gothic-inspired monster literature arouses feelings of regret, sadness, and loneliness (63).

Moreover, monster literature concerns itself with apparent loneliness in its characters, repeatedly showing them to be lonely and helpless. In Frankenstein, both the creator and his monster are alone. Frankenstein obsesses over his scientific revelations and abandons his beloved as well as his family. Once he has completed his scientific creation, he leaves it to fend for itself. Subsequently, the monster kills all of Frankenstein's relatives and friends in order to take revenge, leaving both of them isolated. In Frankenstein, the monster suffers from the profound quietness that fills his environment all the time. He does not see any friendly existence wherever he goes which reminds us of the shared theme of loneliness in the context of monster literature. It is an intertextual element used and reused in many instances where the unholy monster character is treated as the outcast or "the other". Loneliness becomes the hallmark of these characters, and their urge to be seen and recognized becomes one of the main underlying drives that explain their actions and emotions.

\subsection{THE PERSONALITY OF FRANKENSTEIN'S CREATURE}

Different aspects of the creature's personality have been highlighted in the novel and have been adapted in movies in different ways. Jack Pierce's interpretation of Frankenstein's monster from Boris Karloff's classic film version is explained as, "As depicted by Shelley, the monster is a sensitive, emotional creature whose only aim is to share his life with another sentient being like himself. The novel portrays him as intelligent and literate, having read Paradise Lost, Plutarch's Lives, and The Sorrows of Young Werther. He is driven by despair and loneliness to acts of cruelty and murder" (43). 
Due to this situation, the creature is rejected by everyone he encounters, and it becomes a dream for him to find someone with whom to converse. From the first moment of his birth, he realizes that even his own creator does not accept him. It is also clear from the beginning when Frankenstein says "...one hand was stretched out, seemingly to detain me, but I escaped" (Glut 92). As the monster sees his own face, he understands that even he cannot bear to see himself (93). However, his wish is to find acceptance and love from others, but it seems that this wish is impossible to be fulfilled. He swears to take revenge on human beings, especially Frankenstein.

\subsection{THE CONCEPT OF ISOLATION, LONELINESS AND OTHERNESS IN BRANAGH'S FRANKENSTEIN (1994)}

Ideas of monstrosity have proven to be remarkably attractive in film as well as literature. Indeed, the subject of monstrosity and the sense of the uncanny were not only articulated in literature but also became essential to the development of film itself. Mary Shelley's tale of unnatural creation has created and influenced texts ever since the 1818 publication of Frankenstein. Various films present the figure of Frankenstein's revived creature in innumerable fashions, which is now an archetype of western widespread culture (Parker). One hundred and seventy-six years after Frankenstein's appearance, Kenneth Branagh presented his cinematic adaptation of Mary Shelley's seminal work in his adaptation titled Mary Shelley's Frankenstein.

The monster depicted in this adaptation is more human-like and less monstrous, compared to the novel's monster. Its appearance is not overly hideous and is more similar to human beings when compared with other adaptations. A thought-provoking issue is that this monster benefits from free will. The same with the novel's monster, this monster is capable of love and wants to have a mate in order to share this feeling. It is remarkable that when Branagh's creature asks for a mate, it is not satisfied with just any mate. He asks his creator to use Justine's body for the sake of creating the mate; and that is why the creator rejects the whole idea.

Audiences can see more "fidelity of adaptation" in Branagh's adaptation than many others, and the director tries to be loyal to the spirit of the novel. However, throughout the movie, audiences see some differences between Branagh's creature and Mary Shelley's one, but these differences do not have any effect on the main idea of the movie. Branagh's adapted monster does not seem as lonely and isolated as the novel's version as the director attempts to highlight his concept of a monster and the imaginary by bringing a strong image of the creation. This serves to attract the attention of audiences, causing them to think deeply about who really is a monster. It is more capable of human abilities including free will and interaction. The monster's sentiments of loneliness, isolation and otherness are best observed in this version when it spends several months alone in the woods. It seems that according to this film maker, the monster that benefits from more humanity will experience less loneliness. Also the creature is looking for a soul mate which means he does not want to be lonely. He is looking for love.

Both creatures in the novel and film move in the same line to absorb the attention of the audience to sympathize with the creatures. The imagination and creativity of the director in creating Mary Shelley's creature and atmosphere cannot be ignored. Creatures in both the novel and the movie have feelings of love and seek a companion whom they can both love and be loved by. Also, the director and author attempt to portray underlying traces of selfishness in the image of a creator who does not even think about the consequences of his action. Thus, it can be said that Branagh's version has more "fidelity of adaptation" compared to earlier versions.

\subsection{THE CONCEPT OF ISOLATION, LONELINESS AND OTHERNESS IN "THE POST- MODERN PROMETHEUS"}

"The Post-Modern Prometheus" was the fifth episode of the fifth season of the American science fiction television series The X-Files. Loneliness is a major theme in monster literature. In most cases, the outcast monster is rejected by all and thus ends up sad and lonely. "The Post-Modern Prometheus", as with most of the best episodes of "The X-Files", is underpinned by a deep sense of loss. In this particular episode, this manifests itself in the fact that Mulder is unable to find a happy ending to the story without purposefully asking the writer to concoct one for him, leading to an ending which, in all probability, is not even real. Loss and loneliness are twin emotional themes that drive "The X-Files". 
In the series, there is a strong desire among viewers to see Mulder and Scully get together. In essence, it was Carter's idea that the two are a kind of perfect, platonic partnership; a couple who perfectly complete each other, making a sexual encounter unnecessary. At the centre of the show is an emotional core of longing and loneliness. One of the driving forces of the show is that so many of the people who Mulder and Scully meet, both monsters and normal folk, are people who lack that essential 'other half'; people who are constantly searching for something or someone compatible but not finding it. In many episodes, this leads the characters to kill, but in "Prometheus" it leads an old man, no matter how unethically, immorally or haphazardly, to try to create something better, even if he always fails. Strictly speaking, the idea that this old man created most of the town (in an attempt to find a mate for his son) by impregnating women with farm animals and human hybrids, is completely ridiculous and repulsive. The episode's attempt to let the creature off the hook when he admits to everything he did-but not to killing his father-shouldn't work because the townspeople would never accept such terrible crimes, no matter how gullible they may be.

The episode gets away with it for two reasons. Firstly, the sense of isolation; the creature knows he cannot find a mate. Dr Polidori's father does not know what he is doing, and both of them will unavoidably be caught. Whatever anyone wants to blame him for, the creature, as is typical of rejected creatures, is an easy scapegoat. He might be an amusing local legend and the source of a comic book creation, but once he steps into the light he is definitely hideous and ugly. The most offensive parts of the episode are softened in the sense of a father caring for his son and not really knowing what else to do for his happiness. The son lives in an underground room and cannot show his face at night. He loves peanut butter and Cher. He's a monster, but if only he could find his own mate, he might not feel so monstrous any more (Carter 152).

Dr. Polidari's father accuses his actual son of being a real monster. He has more sympathy towards the creature, and wants to create his own monster to act as a companion. He tries to get the FBI agents to ask his son about his scientific achievements. The relationship between Dr. Polidari and his father is not strong, and both of them ignore each other. Even in his work, Dr. Polidari is a selfish scientist. He pays no attention to the consequences of his genetic experiments and the problems they might cause in the future. When Mulder asks why he does those kinds of experiments, he replies very proudly and selfishly: "Because I can". In his personal life, he is a selfish husband. When his wife asks him to have a child, he describes children as small monsters. His wife also suffers from loneliness. He has passion for knowledge, but rather than use it to make life better for people, he is only interested in being recognised for his achievements. Both the creators of the episode and the novel go about portraying selfishness in the same way in not thinking of the consequences of their experimental achievements.

The episode also addresses the fear that these men caused. The old man pays with his life, and the mad scientist is arrested for his murder. The creature is also arrested and sent to jail; even if everyone understands his real motives, he is still guilty of unlawfully entering houses and impregnating women against their will. In attempting to hinder their isolation, these men only created more isolation for themselves. "Prometheus is an episode that starts out as a mistake and ends up becoming extremely sad and oddly horrific, a story where everyone is cruel to each other" (Carter 205).

An important similarity between the creature in the novel and the one in this episode is the fact that both creatures can feel human sentiments including joy, happiness, loneliness and isolation. The Great Mutato asks its creator to provide a mate for him in order to have a companion and stop being miserable and melancholic, which is exactly the same as the demands of the monster in the novel. This fact reveals that no matter what their appearances are, these monsters are all capable of understanding these sentiments and feelings.

When creatures are seen by people, whether in the episode or in the novel, they do not receive love or sympathy. They are regarded as strangers and encounter disgust and hatred in both cases. In fact, this displays how human beings judge solely based on appearance before actually knowing the other person, and this leads to the isolation and loneliness of the monsters. As they are not accepted by society and do not have a mate, they are all alone fighting the whole world in order to make society accept them for who they are. The only difference is that in this episode, people give the monster a chance to talk and explain the whole story. 
After hearing the creature's story, people accepted him as part of society and felt sympathy towards him. They understood that it was not his fault that he was created in such a different way, unlike the novel in which society did not even give the creature the chance to explain what happened to him and immediately rejected him. In the novel, even his creator tries to kill him.

There are two powerful scenes in this episode which draw the attention of audiences and get their sympathy towards the creature; one is when the creature faces his dad's dead body in the house and starts to cry. This is similar to the novel and movie. Later, the creature buries his dad in the barn and cries, showing strong feelings toward his dad who strongly supported him and taught him many things. With the old man gone, he does not have any one else to protect him. His dad tries to create a mate for him and the creator feels loneliness. The second part is when people surrounded him, and he started to explain about himself; that he was an unfortunate product of genetic engineering whose appearance was horrible, but that he never acted to harm other people. His dad rescued him and loved him despite his deformities. He could not go to school or play sports. He emphasizes that he does not have mother to love him, and if he had one then he would be loved like Cher's son who, in the film 'Mask', has a deformed son who is loved. These scenes build up sympathy for the creature.

\subsection{THE CONCEPT OF ISOLATION, LONELINESS AND OTHERNESS IN FRANKENWEENIE (2012)}

Frankenweenie is an American 3D stop motion animated film as well as a comedy-horror family film. Tim Burton, the director of this film, made another short film with the same name in 1984 which was, in fact, a homage to the 1931 film Frankenstein based on Mary Shelley's novel. Frankenweenie contains many references to Shelley's novel and classic horror films, particularly Frankenstein. The title Frankenweenie obviously comes from the same root. Those references spread further as the production records reveal some of the characters' names which clearly allude to Shelley's novel and classic horror films, such as: Victor, Elsa Van Helsing, Edgar "E" Gore and Mr. Burgermeister (Samrick 23). Burton brings Frankenstein to the scene as a young scientist who brings his dog back to life with the same name as the main character in Frankenstein the novel. The reanimation of the dead body also shows a similarity between the novel and Frankenweenie. In Kenneth Branagh`s Frankenstein film, Victor stitches together other dead bodies in order to revive the dead body of his wife (27).

Victor`s science teacher is weird but intelligent, always motivating Victor's mind to bring Sparky back to life, and actually acts as a mentor for Victor. The character was motivated by Burton's childhood picture. Frankenstein in Shelley`s Frankenstein is also inspired by his professor in his university to reanimate corpses by the power of lightning. When Sparky is killed, Victor is inspired by the demonstration of galvanism made by his science teacher and decides to reanimate his dead dog. The provisional electrical apparatus in Victor's attic workshop is made from a bicycle, a toaster, and a Christmas-display rooftop reindeer, among other household items. However, in the novel, Victor has different complicated apparatuses and tools in his laboratory in order to perform his scientific experiments. Again it reflects the simplicity of Frankenweenie (Liu 8). The same as Mary Shelley`s Frankenstein, melancholy is one of the important elements in Frankenweenie as Burton has mentioned the loneliness which exists by an awareness of otherness at an early age never leaves you (Dópido 6).

In contrast to Shelley's Victor Frankenstein, Burton's is younger and more innocent. Burton's version discusses the same themes including love, recreation, science, loneliness and alienation but in a child's world. Therefore, we undoubtedly come across a totally different world in this adaptation. This version illustrates how a child finds it more difficult to lose something because he is not accustomed to the idea yet, and how he would do anything in order to get back what he has lost. An adult who has already lost too many of those who he or she loves finds it easier to adapt and will not try as hard as little Victor did. The monster desperately seeks to create one like himself, so adults may also go to extreme measures too, but then this is not an adult, it is a monster. It could be said, perhaps, that monsters have childlike motivations.

There is a link to connect most of the unworldly creatures of monster literature in that they all have issues of isolation, resentment, loneliness and a lack of sympathy from others that is usually manifested in their actions, thoughts and emotions. In the original novel, the creator himself is afraid of the monster. However, 
in Burton's version, Victor has a nice relationship with what he has created and actually loves the new Sparky. A similarity is that both Victors hide their creatures and do not want others to see what they have made, albeit because of different reasons. In the novel, Victor is afraid of his creature, abhors it and knows the monster will not be accepted by society which is why he hides it away. In the cartoon, Victor does not think his creature is ugly or dangerous by any means, but he knows that the recreated dog which is charged by electricity will not be accepted by others. So, though the reasons sound different, the new creatures are unlike their normal counterparts and are not accepted or liked by others. Therefore, they are alienated, isolated and lonely. One must realize, however, that the fact that these creations are "other worldly" is what makes their creators hide them, so in a way, a central notion is acceptance, or lack thereof, of the "other".

However, there are moments in each version where the monsters are actually accepted. In the novel, the blind man cannot see the monster's appearance and therefore considers the monster as kind and warmhearted and is not afraid of him. In Burton's version, when Sparky rescues Elsa's pet, people finally feel sympathy for the new Sparky and accept the dog. And when the dog dies because of doing so, they ask Victor to revive the dog using their car batteries. In a way, one comes to the conclusion that despite your appearance, one can make an impression on the masses by way of his/her deeds. Also a small point to be made here is that, in most of these works, ordinary people are also shown to have "monstrous" sides to them too, but these can also be reversed.

The differences and similarities of the relationship between the creator and creature in these two cases may perhaps be explained by the concept of "love". The new Sparky is created because Victor longed to have his dog back. Victor recreates the dog and reanimates it using electricity not as a mere science experiment but in order to restore his beloved pet to life. His classmates do the same to other dead animals, even ones which they did not love, solely to participate in the science fair; therefore, they created monsters that were hideous, frightening, dangerous and of no use. This is a relatively new concept put forth by Burton. In Shelly's novel, the creature is not made because of love. The creator is a scientist who pursues science more than anything else. He wants to create a living being just to show that he is capable of doing anything using science. It is his ego that is at stake, not his love, and as is the case in many of these classic works of fiction, one's ego tends to push oneself to oblivion.

Another similarity between Burton's and Shelly's versions is that both creatures are capable of love. The novel's creature wants to have relationships with other beings and try to make friends with others. It is the same for the revived Sparky. The new Sparky loves Elsa's pet. In fact, the film ends when they kiss each other. So most of these creatures exhibit human attributes and emotions, but they are not appreciated in the more classical approaches. A sort of de-familiarization is carried out to remove us from our comfort zone and make us understand better this important fact. Burton does this in a truly formalist way and uses it extensively in his work.

Who is the monster in Frankenweenie? There may be many answers to this question. Science may be considered as the real monster. It is science which causes all these problems. If the science teacher had not shown Galvani's dead frog experiment to students, his students including Victor would have been unaware of the idea. The science teacher is regarded as a monster by parents. They do not let him keep teaching in the school because they believe he pollutes children's minds. Little Victor can also be mentioned as the monster because it is he who starts recreating dead animals and causes all these problems for the whole city. Compared to the novel, the new Sparky should be the monster. However, Sparky is not really a monster. The creature is not hideous, huge or cruel. It is a small dog with stiches who loves and is loved. It is not dangerous to others and even helps them. The new Sparky is lonely because its creator believes that others will never accept a recreated dog that is charged by electricity. However, he is totally wrong. The recreated dog is the same as the old Sparky. The only difference is that the new Sparky has stiches and should be charged with electricity. The new Sparky looks different from the old one but is as kind and affectionate as the previous one.

\subsection{CONCLUSION}

The novel is actually a classic tale of social awareness, a story of one looking for acceptance and asking for companionship but being banned and branded a monster. His loneliness finally drives him to kill his creator 
and himself. While The Modern Prometheus expresses the story of The Great Mutato, chaotic and insecure from its very first day, he lives in the woods while observing humanity from a distance, learning to make a fire, how to find food, and how to distinguish between feelings of sadness, happiness, and being alone. It seems that the concepts of loneliness and alienation are better understood by modern spectators as a postmodern aspect of existence reflected in a postmodern adaptation for a postmodern audience, an audience that is more familiar with feelings of alienation and rejection.

This is where the two stories meet and the monster in Frankenstein pleads with Victor saying he's 'a good creature turned bad by unforgiving humans who scoffed at friendship'. The monster begs Victor to make him a companion which he would take and never be heard from again. Victor reluctantly agrees but finds it incredibly difficult to do so, even though his family is in danger. Victor realizes that he may, by giving a partner to the monster, be creating more monsters in the process as they may procreate. The monster in Frankenstein swears to take revenge by killing everyone close to Victor in an effort to demonstrate to Victor what it feels like to be alone. In the same respect, The Great Mutato also suffers from loneliness, and the father of the scientist wants to make a mate for him so he would not be alone anymore (Bartter).

The creatures in Branagh's Frankenstein the movie and the original novel are similar. Branagh creates a creature that is exactly the same as Mary Shelley's. The director tries to use the author's thoughts and merges it with his own concepts of the monster and creates a faithful manifestation Marry Shelley's creature. Both of the creatures in these two mediums suffer from loneliness and isolation. Even the creator does not accept him. Frankenstein had only created the monster because of his passion and selfishness without attention to the consequences of his deed. So, he rejects his own creature. Both creatures look for a mate and ask their creator to make one for him but Frankenstein refuses. Instead of feeling sympathy, he tries to kill his own creation. Although Dr. Frankenstein tries to kill him, when Victor dies at the end, the only one beside him is his own creature who feels sorrow and grief and cries for his creator who had tried to kill him. In a nutshell, this adaptation can be placed in the first category of Geoffrey Wagner's theory called transposition because the novel is adapted directly to the screen with slight changes as mentioned before. Other scholars, like Dudley Andrew, discuss this kind of adaptation as "fidelity of adaptation". He states that the movie and the original novel are related. Based on the earlier discussion, this movie falls into the category of "fidelity of adaptation" and the director has fidelity towards the author of the novel.

In "Post- Modern Prometheus", the creature is made by genetic engineering unlike the original Mary Shelley's creature in the novel which is made of different dead parts of human bodies. Both creatures here are literate but one learnt from the family in a cottage while the other one learns from an old man. Here, unlike Mary Shelley's creature, there is an old man who loves this creature and supports him, but both creatures suffer from loneliness and isolation. They are looking for a mate and someone to love them. Neither of these two creatures harm anyone but both are rejected by their selfish creators. Dr. Polidari even tells the creature it was a mistake. In contrast, while Mary Shelley's society does not accept him, the society in Carter's adaptation accepts him after they let the creature talk about his situation.

Frankenweenie is a gathering of elements from classic thriller-horror movies. In particular, the greatest connection to make is to Mary Shelley's classic gothic novel, Frankenstein, in which the holy barrier of divinity is broken and man plays God and so brings onto himself the hate of the world. The boy's name is the same as the scientist in Frankenstein who reanimates the corpse (dog) to life, and also similar is the lonely nature of both of the main characters (Samrick 25). Also growing up around the horror films of his time, such as House of Frankenstein, House of Dracula and Frankenstein Meets the Wolfman, Burton draw many similarities in the characters he created (Topel 4).

\section{REFERENCES}

Andrew, Dudley. Concepts in Film Theory. March 15, Oxford, 1984. Print.

Bartter, Martha A., ed. The Utopian Fantastic: Selected Essays from the Twentieth International Conference on the Fantastic in the Arts: Greenwood Publishing Group, 2004.

Bazin, Andre. What Is Cinema? Trans. Hugh, Gray. Vol. 1. Berkeley, Los Angeles, and London: U of California P, 1976. Print. 
Glut, Donald F. The Frankenstein Archive: Essays on the Monster, the Myth, the Movies, and More. McFarland, 2002. Print.

Jackson, Tony E. The Technology of the Novel: Writing and Narrative in British Fiction. Johns Hopkins UP, 2009. Print.

Liu, Qina. "Review: "Frankenweenie" Takes a Twist on a Classic Tale." The Ithacan (2012). Print.

Parker, Sabadino. "Masculine Revisioning in Kenneth Branagh's Mary Shelley`S Frankenstein." GeoCities (2009): 5. Print.

Samrick, Julie. "'Frankenweenie' Pays Homage to Classic Horror." 2012.

Sanders, J. Adaptation and Appropriation. London: Routledge, 2006. Print.

Topel, Fred. "Comic-Con 2012: Tim Burton on Frankenweenie." July 13th, 2012. 